\title{
Nostolepis scale remains (stem Chondrichthyes) from the Lower Devonian of Qujing, Yunnan, China
}

\author{
Qiang Li ${ }^{1,2,3}$, Xindong Cui ${ }^{3,4}$, Plamen Stanislavov Andreev ${ }^{1,3}$, Wenjin Zhao ${ }^{3,4,5}$, Jianhua Wang ${ }^{1}$, Lijian Peng ${ }^{1}$, Min $^{2}$ \\ Zhu ${ }^{\text {Corresp. 3, 4, } 5}$ \\ 1 Research Center of Natural History and Culture, Qujing Normal University, Qujing, China \\ 2 Chongqing Institute of Geology and Mineral Resources, Chongqing, China \\ 3 Key CAS Laboratory of Vertebrate Evolution and Human Origins, Institute of Vertebrate Paleontology and Paleoanthropology, Chinese Academy of \\ Sciences (CAS), Beijing, China \\ 4 University of Chinese Academy of Sciences, Beijing, China \\ 5 CAS Center for Excellence in Life and Paleoenvironment, Beijing, China \\ Corresponding Author: Min Zhu \\ Email address: zhumin@ivpp.ac.cn
}

Based initially on microfossils, Nostolepis is one of the first known 'acanthodians', which constitute a paraphyletic assemblage of plesiomorphic members of the total group Chondrichthyes. Its wide distribution has potential implications for stratigraphic comparisons worldwide. Six species of Nostolepis have been reported in China, including one species from the Xitun Formation (Lochkovian, Lower Devonian) of Qujing, eastern Yunnan. Acid preparation of rock samples from the Xitun Formation has yielded abundant acanthodian remains. Based on both morphological and histological examinations, here we identify five species of Nostolepis, including two new species. N. qujingensis sp. nov. is characterized by thin scales devoid of the neck anteriorly and the dentine tubules rarely present in the anterior part of the crown. N. digitus sp. nov. is characterized by parallel ridges on anterior and lateral margins of the crown, and the neck constricted and ornamented with pore openings. We extend the duration of $N$. striata in China from the Pridoli of Silurian (Yulungssu Formation) to the Lower Devonian in Qujing and report the first occurrences of $N$. amplifica and $N$. consueta in this region. This study increases the diversity of the Lower Devonian Xitun Fauna and provides a better understanding of the paleogeographic distribution of Nostolepis. 
1 Nostolepis scale remains (stem Chondrichthyes) from 2 the Lower Devonian of Qujing, Yunnan, China

3

4

5

6

7

8

9

10

11

12

Qiang $\mathrm{Li}^{1,2,3}$, Xindong Cuij,4, Plamen Stanislavov Andreev ${ }^{1,3}$, Wenjin Zhao ${ }^{3,4,5}$, Jianhua Wang $^{1}$, Lijian Peng ${ }^{1}$, Min Zhu ${ }^{3,4,5}$

${ }^{1}$ Research Center of Natural History and Culture, Qujing Normal University, Qujing 655011, Yunnan Province, China.

${ }^{2}$ Chongqing Institute of Geology and Mineral Resources, Chongqing 401120, China.

${ }^{3}$ Key CAS Laboratory of Vertebrate Evolution and Human Origins, Institute of Vertebrate Paleontology and Paleoanthropology, Chinese Academy of Sciences (CAS), Beijing 100044, China.

${ }^{4}$ University of Chinese Academy of Sciences, Beijing 100049, China.

${ }^{5}$ CAS Center for Excellence in Life and Paleoenvironment, Beijing, China Corresponding Author:

Min Zhu

Beijing, 100044, China

Email address: zhumin@ivpp.ac.cn

\section{Abstract}

Based initially on microfossils, Nostolepis is one of the first known 'acanthodians', which constitute a paraphyletic assemblage of plesiomorphic members of the total group Chondrichthyes. Its wide distribution has potential implications for stratigraphic comparisons worldwide. Six species of Nostolepis have been reported in China, including one species from the Xitun Formation (Lochkovian, Lower Devonian) of Qujing, eastern Yunnan. Acid preparation of rock samples from the Xitun Formation has yielded abundant acanthodian remains. Based on both morphological and histological examinations, here we identify five species of Nostolepis, including two new species. $N$. qujingensis sp. nov. is characterized by thin scales devoid of the neck anteriorly and the dentine tubules rarely present in the anterior part of the crown. $N$. digitus sp. nov. is characterized by parallel ridges on anterior and lateral margins of the crown, and the neck constricted and ornamented with pore openings. We extend the duration of $N$. striata in China from the Pridoli of Silurian (Yulungssu Formation) to the Lower Devonian in Qujing and report the first occurrences of $N$. amplifica and N. consueta in this region. This study increases the diversity of the Lower Devonian Xitun Fauna and provides a better understanding of the paleogeographic distribution of Nostolepis.

\section{Introduction}

The Lower Devonian Xitun Formation exposed in Qujing, China has yielded a significant early vertebrate fauna, whose macrofossils are represented by jawless galeaspids and 
42 jawed members such as 'placoderms' and osteichthyans (Chang, 1982; Chang \& Yu, 43 1984; Zhu, 1996; Zhu, Yu \& Janvier, 1999; Zhu, Yu \& Ahlberg, 2001; Zhu \& Yu, 2002;

44 Zhu et al., 2006). Probably due to the micromeric (small scales or tesserae on the head, 45 rather than macromeric, with large dermal bones) skeletal nature of conventionally46 defined chondrichthyans and 'acanthodians', no cranial remains of the two groups have 47 been found in the Xitun Formation, although microfossils from the same bonebeds have vertebrate phylogeny suggest that conventionally-defined chondrichthyans and 'acanthodians' form a clade, i.e. the total group Chondrichthyes, whose micromeric skeleton probably evolved from an ancestral macromeric condition possessed by 'placoderms' and osteichthyans (Brazeau, 2009; Davis, Finarelli \& Coates, 2012; Zhu et al., 2013; Giles et al., 2015; Long et al., 2015; Burrow et al., 2016). A better understanding of the chondrichthyan members from the Xitun Formation will provide a further glimpse of the diversity of jawed vertebrates in South China during the Early Devonian.

Nostolepis is a cosmopolitan acanthodian genus erected by Pander (1856) for scales. It was generally assigned to the family Climatiidae of the order Climatiiformes for the latter half of the twentieth century (Berg, 1940; Gross, 1957; Gross, 1971; Denison, 1979; Tông-Dzuy \& Janvier, 1994; Burrow, 1997; Miller \& Märss, 1999; Vergoossen, 2002a; Valiukevičius, 2003c; Wang, 2003; Vergoossen, 2004). However, Burrow et al. (2006) referred it to the Climatiidae order indet. Considering that Nostolepis lacks circumorbital bones, dermal pectoral girdle, and branchial plates, Burrow \& Turner (2010) doubted its assignment to the Climatiidae. So far, the order and the family for Nostolepis have been uncertain (Burrow \& Murphy, 2016).

Nostolepis was first reported in China as Nostolepis sp. indet. from the Xitun Formation (Lochkovian, Lower Devonian) in Qujing (Wang, 1984). The first nominal species of Nostolepis in China is N. sinica from the Yulungssu Formation (Pridoli, Silurian) in Qujing (Gagnier, Jahnke \& Yan, 1989). Soon after, N. striata and N. sp. were described from the same horizon in Qujing (Wang \& Dong, 1989). N. striata was also recorded from the Xiaputonggou Formation (Lochkovian) in West Qinling (Wang et al., 1998) and the Shanjiang Formation (Homerian, Wenlock) in Lijiang, Yunnan (Wang, 2003). N. gracilis was described from the Alengchu Formation and Shanjiang Formation (Wenlock, Silurian to Emsian, Lower Devonian) in Lijiang, Yunnan (Wang, 2003) and the Xiaputonggou Formation (Lochkovian) in West Qinling (Wang et al., 1998). From the latter site, Wang et al. (1998) also described N. tewonensis from Homerian (Wenlock, Silurian) to Lochkovian. Nostolepis guangxiensis was reassigned to Nostovicina guangxiensis because its crown lacks the Stranggewebe (Valiukevičius \& Burrow, 2005).

Here, we describe five species of Nostolepis, including two new species, from the Xitun Formation in Qujing, Yunnan, China, thus increasing the diversity of the Early 
82 Devonian Xitun Fauna. We also summarize and discuss the paleogeographic

83 distribution and chronological extensions of Nostolepis species.

84

85

86

87

88

89

90

91

92

93

94

95

96

97

98

99

100

101

102

103

104

105

106

107

108

109

110

111

112

113

114

115

116

117

118

119

120

121

\section{Materials \& Methods}

This study is based on isolated scales of Nostolepis from the Xitun Formation (Lochkovian, Lower Devonian) in Xitun, Xishan subdistrict, Qujing, Yunnan, China $\left(\mathrm{N}: 25^{\circ} 31.547^{\prime}, \mathrm{E}: 103^{\circ} 31.547^{\prime}\right)$. Studied scales were extracted by treatment with buffered $5 \%$ acetic acid from greenish-yellow muddy limestone of the Xitun Formation at the laboratory of Qujing Normal University.

Thin sections were prepared by embedding scales in epoxy resin. The cured resin blocks were cut with a low speed saw and 100-200 mm away from embedded specimens. Then the surface was ground with sand paper with grit sizes ranging from P600 to P4000 until the desired surface of the specimen was exposed. This surface was polished with a grinder/polisher and glued to a glass slide. Finally, the other surface was cut, ground and polished in the same way to produce doubly-polished thin sections. Scales of each species were sectioned in vertical longitudinally, vertical transversely and horizontally. Scanning electron microscope (Hitachi S-3700N) was used to take images of intact scales. All specimens are housed in the collection of the Institute of Vertebrate Paleontology and Paleoanthropology (IVPP), China.

The electronic version of this article in Portable Document Format (PDF) will represent a published work according to the International Commission on Zoological Nomenclature (ICZN), and hence the new names contained in the electronic version are effectively published under that Code from the electronic edition alone. This published work and the nomenclatural acts it contains have been registered in ZooBank, the online registration system for the ICZN. The ZooBank LSIDs (Life Science Identifiers) can be resolved and the associated information viewed through any standard web browser by appending the LSID to the prefix http://zoobank.org/. The LSID for this publication is: urn:Isid:zoobank.org:pub:C3957E52-DD5E-438E-BCD2-515B1611D9C2. The online version of this work is archived and available from the following digital repositories: PeerJ, PubMed Central and CLOCKSS.

\section{Results}

Systematic paleontology

'Acanthodii' Owen, 1846

Order and Family Incertae sedis

Genus Nostolepis Pander, 1856

Nostolepis striata Pander, 1856

1856 Nostolepis striata, Pander, pl. 28, figs. 1, 7.

1984 Nostolepis sp., Blieck et al., pl. 1, figs. 3-4. 
122

123

124

125

126

127

128

129

130

131

132

133

134

135

136

137

138

139

140

141

142

143

144

145

146

147

148

149

150

151

152

153

154

155

156

157

158

159

160

161

162

1997 Nostolepis striata, Burrow, figs. 2A-B; pl. 1, figs. 13A-C; pl. 2, figs. 1-4. 1998 Nostolepis striata, Valiukevičius, pl. 1, figs. 1-4; pl. 2, figs. 4-7. 1998 Nostolepis striata, Wang et al., pl. 1, figs. B-C. 1999 Nostolepis striata, Vergoossen, pl. 2, fig. 15. 2002b Nostolepis striata, Vergoossen, pl. 3, figs. 26-36. 2003a Nostolepis striata, Vergoossen, pl. 6, figs. 71-76. 2003b Nostolepis striata, Vergoossen, pl. 10, figs. 85-100. 2003 Nostolepis striata, Wang, fig. 1. 2004 Nostolepis striata, Vergoossen, pl. 5, figs. 54-61. 2005 Nostolepis striata, Valiukevičius, fig. 3L and M. 2013 Nostolepis striata, Burrow et al., figs. 3, 4.1 and 4.2. 2018 Nostolepis striata, Turner and Burrow, figs. 6A-D. Other synonyms see Valiukevičius (1998).

Referred Chinese Material: 68 trunk scales (IVPP V26830.1-V26830.68). Description:

Morphotype 1 (Figs. 1A-D):

This type of scales has a broad triangular, flat, or slightly inclined crown. Crowns are about $0.21-0.56 \mathrm{~mm}$ long and $0.28-0.51 \mathrm{~mm}$ wide. Three to four short, stout, longitudinal and converging ridges bend inward from the anterior face of the crown to a quarter of the crown's length. The distal pointed end of the crown overhangs the base slightly. Most of the scales have two smooth lateral slopes rising from the anterior crown-neck boundary and joining at the pointed posterior apex. The neck is smooth and indistinctive. The rhomboid base is strongly or moderately convex and its outline matches that of the crown except for the crown's posterior end.

Morphotype 2 (Figs. 1E-H):

One triangular scale form has an inclined crown surface with an angle of nearly $30^{\circ}$. The crowns are slightly wider than long $(0.5 \mathrm{~mm}$ wide and $0.3 \mathrm{~mm}$ long). Two strong ridges are running back from the anterior crown margin to one-third of the crown length with 1-3 subparallel ridges between them. The ridges slope down almost to the base rim anteriorly, thus distinctly lowering the scale's anterior neck. The lateral slopes of the crown are sharp and well developed. The neck is short, smooth anteriorly, deeper and more concave posteriorly. The base is rhomboid and moderately convex. Histology (Figs. 2A-B):

The scales of the first and second varieties have the same histology. The crown is composed of 3-4 odontodes, which are thick on top and sides. All the odontodes are filled with a network of dentine tubules. The canal system is visible on the crown's posterior part, but Stranggewebe only present in the primordial odontode. The base is pyramid-shaped and is composed of cellular bone. Long Sharpey's fibers penetrate the base radially.

Remarks: 
163 Nostolepis striata has been frequently redefined since it was erected by Pander (1856) 164 for scales from Estonia. Gross (1947) reassigned some acanthodian species, erected 165 by Brotzen (1934) and Lehman (1934), to Nostolepis striata. Vergoossen (2002b) 166 agreed with this assignment, but thought the morphological variations of $N$. striata were still too large. After careful observation, Vergoossen (2002b) defined seven different morphotypes according to the Nostolepis scales from Klinta, southern Sweden. We follow his classification and recent descriptions by Burrow et al. (2013) and Turner \& Burrow (2018). We suggest two kinds of morphotypes here based on the new materials from the Xitun Formation. We combine morphotypes 1, 2 and 6, defined in Vergoossen (2002b), within one group, and morphotypes 3 and 7 within another group. This second kind of scales comprises pinnal scales or tesserae as in Turner \& Burrow (2018). Both morphotypes have the typical Nostolepis structure with mesodentine and Stranggewebe.

175

\section{Nostolepis amplifica Valiukevičius, 2003c}

1984 Nostolepis sp. indet., Wang, figs. 3D-F.

1989 Nostolepis sinica, Gagnier et al., pl. 1, figs. 3-4?

1999 Nostolepis striata, Vergoossen, pl. 2, figs. 16-17.

2003c Nostolepis amplifica, Valiukevičius, figs. 2A-H and 3.

2005 Nostolepis amplifica, Valiukevičius, figs. 2A-B.

Referred Chinese Material: 42 trunk scales (IVPP V7216.4, IVPP V26832.1-V26832.41). Description:

Morphotype 1 (Figs. 11-N):

The scale crown's length and width range from $0.32-0.66 \mathrm{~mm}$ and $0.31-0.65 \mathrm{~mm}$, respectively. Morphotype 1 is elongated with rhombic to ellipsoidal in outline. The crown surface is side to side and inclined, with one-fourth of the crown's length overhanging the base posteriorly. Two longest prominent ridges from an elevated median area of the crown, are sculptured by 2-6 rounded, short, subparallel anterior ridges. Most scales have an unsculptured lateral slope on each side of the median area, but some have several ridgelets (Figs. $1 \mathrm{M}-\mathrm{N}$ ), which are finer and lower than those on the median area. The neck is well defined and constricted. A row of 3-5 regularly spaced small openings are located on each side of the neck, and sometimes they are also visible anteriorly below the ridges (Fig. 1I-L). The convex and rectangular base is equal or slightly larger than the crown.

Morphotype 2 (Figs. 10-P):

These scales have an inclined median crown surface with two strong main ridges and two inconspicuous lateral slopes on each side of the median area. Crown length varies from $0.60-0.75 \mathrm{~mm}$ and width from $0.50-0.65 \mathrm{~mm}$. A shallow and wide longitudinal groove between the two central ridges is another characteristic, forming an incised anterior crown margin. The neck has a row of regularly spaced small openings locating 
203

204

205

206

207

208

209

210

211

212

213

214

215

216

217

218

219

220

221

222

223

224

225

226

227

228

229

230

231

232

233

234

235

236

237

238

239

240

241

242

on the side or below the ridge. The scale base of both morphotypes is shaped from isometric to asymmetric rhomboid, sometimes wider than long. The base protrudes anteriorly beyond the crown. It is moderately deep to deep, with the deepest point locating centrally or anteriorly.

Histology (Figs. 2C-D):

The structures of tissues are similar in the two types. The crown is composed of mesodentine but the stranglacunae are not visible due to the recrystallization. The winding and short dentine tubules orient upwards. Ascending and vaulted vascular canals can be seen in the posterior part of the crown. Stranggewebe is short, narrow, and medium dense, developing only in the first and second lamellae on the crown's posterior part. The base consists of cellular bone with osteocytes.

Remarks:

This species was erected by Valiukevičius (2003c) for scales from Pridoli and Ludlow of Lithuania. Valiukevičius (2003c) indicated that $N$. amplifica was similar to the specimens of N. striata described by Vergoossen (2002b) (pl. 14, figs. 85-87) obtained from ÖvedRamsåsa, the Sandstone Formation, Ludlow to Pridoli and Vergoossen (2000) (pl. 1, figs. 4-5 and 7-8), obtained from Welsh Borderland, Silurian to Devonian. We consider that the specimens described by Vergoossen (2002b) (pl. 14, figs. 85-87) should be assigned to $N$. striata as originally suggested. Morphologically, $N$. amplifica is similar to $N$. striata, and the former usually has a shallow and longitudinal groove between the two central ridges. Another difference is that the neck has a row of regularly spaced small openings for $N$. amplifica, but it is rarely reported for $N$. striata. Only two exceptional specimens with neck openings were reported in $N$. striata, which differ from the trunk scales described by Gross (1947), pl. 7, fig. 13 and Gross (1971), pl. 5, fig. 3a. Histologically, Valiukevičius (2003c) also figured that both species have similar mesodentine, Stranggewebe, vascular canals, and large number of osteocytes, but the canal system is more advanced and Stranggewebe is shorter and denser in $N$. amplifica. N. amplifica was first found by Wang (1984) (figs. 3D-F) and described as Nostolepis sp. indet. from the Xitun Formation. In terms of morphology, some specimens described by Gagnier et al. (1989) (pl. 1, figs. 3-4) from the Yulungssu Formation, Hongmiao (Shiyanpo), Qujing, which differ from the holotype of $N$. sinica (pl. 1 , figs. 1-2), probably belong to $N$. amplifica.

Nostolepis consueta Valiukevičius, 2003c

1984 Nostolepis sp. indet., Wang, figs. 3A-C.

1997 Gomphonchus sandelensis? Märss, pl. 3, fig. 5.

1998 Nostolepis minima, Valiukevičius, pl. 1, fig. 5.

1998 Nostolepis sp. or Cheiracanthoides sp., Valiukevičius, pl. 1. figs. 10-15.

1998 Nostolepis striata, Wang et al., pl. 1, fig. A.? 
243

244

245

246

247

248

249

250

251

252

253

254

255

256

257

258

259

260

261

262

263

264

265

266

267

268

269

270

271

272

273

274

275

276

277

278

279

280

281

282

2003c Nostolepis consueta, Valiukevičius, figs. 5A-I, 6 and 7.

2005 Nostolepis consueta, Valiukevičius, figs. 2E-F.

Emended diagnosis: The crowns are flat, never inclined, and sculptured with 6-12 short and parallel ridges. Low anterior ridges fade out at one-third of the crown's length. The posterior part of the crown is composed of Stranggewebe and widened ascending vascular canals. The Stranggewebe is dense in each odontode.

Referred Chinese Material: around 24 trunk scales (IVPP V7216.7, IVPP V26834.1V26834.23).

Description (Figs. 1Q-X):

The scale crown is flat, never inclined, and has a nearly triangular or ovoid shape.

Crown length varies from $0.37-0.70 \mathrm{~mm}$ and width from $0.41-0.55 \mathrm{~mm}$, respectively.

Most of the scale crowns have 3-12 subparallel and short ridges extending one-third of the crown's length, converging towards the posterior end. Lateral slope lobes are not well developed in most of the scales. The anterior edge of the crown is convex, curving down to the base. The neck is smooth and constricted for most of the scales. A rhombic base is slightly convex, anteriorly vaulted, so that the base protrudes in front of the crown.

Histology (Figs. 2E-F):

The crown has a relatively big primordial scale and a few growth lamellae thin on top but thick on anterior and posterior parts. The odontodes have dentine tubules, which are dense anteriorly. The crown's posterior part is composed of Stranggewebe and widened ascending and vaulted vascular canals (over the base). Stranggewebe is short and densely presented in each odontode. The base is composed of compact, thin-lamellar bone, containing a large number of osteocytes.

Remarks:

For trunk scales, Valiukevičius (2003c) identified two morphotypes of $N$. consueta. The first morphotype has 8-12 ridges, and the second morphotype has fewer than 6 ridges. In our collection, most of the referred scales have 6-10 ridges. $N$. consueta is so similar to $N$. striata that some $N$. consueta probably have been misassigned to the latter. $N$. consueta has a flat crown, never inclined, and the anterior corner of the crown is markedly angular. More differences are present in the histological features. N. consueta has dense Stranggewebe in each odontode; $N$. consueta has a low number of osteocytes and no obvious Sharpey's fibers in the base compared with $N$. striata. The scales assigned to Nostolepis sp. indet. (Wang, 1984, figs. 3A-C) should be Nostolepis striata. And the specimen (V11528.1) described as Nostolepis striata (Wang et al. 1998, pl. 1, fig. A) from the lower Lochkovian Xiaputonggou Formation, West Qinling, China, probably belong to $N$. consueta.

Nostolepis qujingensis sp. nov. 
283

284

285

286

287

288

289

290

291

292

293

294

295

296

297

298

299

300

301

302

303

304

305

306

307

308

309

310

311

312

313

314

315

316

317

318

319

320

321

Deviation of name: After Qujing city, the fossil site.

Holotype: IVPP V26838.1.

Type locality and horizon: Xitun, Xishan subdistrict, Qujing, Yunnan, China; Xitun

Formation, Lochkovian, Lower Devonian.

Referred Material: 16 trunk scales (IVPP V26838.1-V26838.16)

Diagnosis:

Trunk scales are of moderate size, ornamented with longitudinal ridges in the crown. Crown length is $0.3-0.5 \mathrm{~mm}$, width $0.3-0.5 \mathrm{~mm}$. The distal pointed end of the crown always overhangs the base at one-third of its length. The angle between crown and base can reach $45^{\circ}$ maximally. The neck is absent anteriorly, but deeper and concave posteriorly. The base is rhomboid, thin, and concave. Dentine tubules rarely present in the anterior part of the crown. Scale base is composed of bone with few osteocytes. Description (Figs. 3A-H):

The scale crowns are triangular in shape or irregularly shaped (Figs. 3E-H). They incline antero-posteriorly at an angle of $30^{\circ}-45^{\circ}$. Crown length varies from $0.33-0.50$ $\mathrm{mm}$ and width from $0.36-0.51 \mathrm{~mm}$, respectively. The crown is sculptured with slightly sinuous ridges extending the whole surface (Figs. 3A-D) or ornamented with radial ridges and deep grooves (Figs. 3E-H). The lateral slope usually develops in the former morphotype (Figs. 3A-D). The neck is absent anteriorly, but deeper and concave posteriorly. The base is rhomboid and thin, never protrudes beyond the crown on all sides.

Histology (Figs. 4A-D):

The crown's odontodes are very thin, and the dentine tubules are rarely present in each odontode. Wide vascular canals rise from the neck and penetrate the posterior part of the crown. Scattered osteocytes form a low and flat base.

Remarks:

Nostolepis qujingensis is similar to $N$. lineleyensis in the crown sculptured with ridges and grooves at the anterior margin, sloping down at an angle of $30^{\circ}-45^{\circ}$. But $N$.

lineleyensis has a much thicker crown and more ridges than $N$. qujingensis. More differences are found in histology. $N$. qujingensis and $N$. lineleyensis have a similar system of vascular canals, but the latter has a typical mesodentine in the crown and cellular bone with numerous large and elongate osteocytes (Miller \& Märss, 1999).

Nostolepis digitus sp. nov.

Derivation of name: From the Latin digitus, referring to the appearance of the crown ornamentation.

Holotype: IVPP V26840.1 
322 Type locality and horizon: Xitun, Xishan subdistrict, Qujing, Yunnan, China; Xitun

323 Formation, Lochkovian, Lower Devonian.

324 Referred Material: 25 trunk scales (IVPP V26840.1-V26840.25).

325 Diagnosis:

326 Large-sized scale having a sub-rhomboid crown with rounded and widened anterior

327 edge and a slightly tapered posterior end. Short and parallel ridges on the crown's

328 anterior and lateral margins, curving down to the base. The neck is constricted with

329 small pores. Scale bases are strongly convex; their maximum depth is slightly in front of

330 the center. Dentine tubules are dense in each odontode of the crown, and the

331 Stranggewebe is oriented parallel to the growth zone lines and distributed in the

332

333 posterior part of the odontodes. Ascending vascular canals are well developed. The base is filled with numerous osteocytes.

334 Description (Figs. 3I-P):

335 Scale crowns are usually flat, or slightly inclined. Crown length varies from $0.45-0.76$ $336 \mathrm{~mm}$ and width from $0.41-0.70 \mathrm{~mm}$. The rhombic crown has a round and wide anterior edge and a blunt posterior cusp. The posterior parts of crowns tilt to one side. The crown is ornamented with short and parallel ridges that do not extend to the middle of the crown posteriorly, but bend down anteriorly and laterally. The crown has a smooth lateral slope flanking the posterior part. The neck is short, lowered anteriorly, but deeper and concave posteriorly. Only small pores are visible on the neck. The base is strongly convex, vaulted anteriorly and protruding in front of the crown. Histology (Figs. 4E-H): The crown is composed of 3-4 odontodes, and the young one envelops the older one completely. Dentine tubules are dense and discernable in each odontode. The growth lamella contains long ascending vascular canals placed posteriorly in the neck over the scale base. The Stranggewebe is oriented parallel to the growth zone lines and only presented in the posterior part of the outermost odontode. The upper surface of the base forms a high pyramid, and the base is filled with many osteocyte cavities. Remarks:

The referred specimens are similar to Nostolepoides mingyinensis in morphology and histology, which was described from another Devonian site in Yunnan Province (Wang, 2003) (p. 8, fig. 3). Morphologically, the crowns of both species are rhomboid, sculptured with short and parallel ridges, not extending half of the crown length, and the lateral slopes are less developed. N. minyingensis has very sharp ridges and anterior crown margin, and $N$. digitus has short rounded ridges and crown margin. Histologically, their base tissues are similar in having dense osteocytes. The Stranggewebe is not visible in Nostolepoides mingyinensis, and the crown is composed of more odontodes. Morphologically, $N$. digitus is also similar to Nostolepis sp. aff. N. multicostata reported by Burrow et al. (2006) (figs. 3, 11-12 and 15-16) from the Lower Devonian Jawf Formation of northwestern Saudi Arabia. But the Arabian form is much larger than $N$. digitus, and its crown has more ridges. 


\section{Discussion and Conclusion}

365 Valiukevičius \& Burrow (2005) classified the acanthodian scales with Nostolepis-like

366

367

368

369

370

371

372

373

374

375

376

377

378

379

380

381

382

383

384

385

386

387

388

389

390

391

392

393

394

395

396

397

398

399

400

401

402

403

histology into five groups based on the presence or absence and extent of the Stranggewebe, and different types of dentine tubules in scale crowns, which we follow here. Only the scales composed of typical Stranggewebe and simple odontocytic mesodentine in the crowns are referred to Nostolepis, which is in accordance with the classical diagnosis of Nostolepis (Pander, 1856; Gross, 1971).

The new Nostolepis microfossils in this study indicate a high diversity of 'acanthodian' taxa in the Xitun Formation. So far, 33 acanthodian species have been described from the Silurian and Devonian of China, including nine species of Nostolepis in total (Fig. 6). The other 31 Nostolepis species from the rest of the world are also listed here (Fig. 6). Here, we focus on the biostratigraphic and paleogeographic distribution of the Nostolepis species from China and discuss their potential biogeographic implications.

As shown in Fig. 6, most Nostolepis species have been recorded from the Pridoli to Lochkovian, except for $N$. infida that was recorded in the Emsian. N. musca and N. terraborea were found in the beds from the Ludlow to Pridoli, and the earliest records of $N$. consueta, $N$. tewonensis, $N$. gracilis and $N$. striata are back to the Wenlock (Denison, 1979; Gagnier et al., 1989; Wang \& Dong, 1989; Wang et al., 1998; Wang, 2003; Valiukevičius, 2005; Burrow, 2013; Turner \& Burrow, 2018; Wang, 2018). N. kernavensis and $N$. gaujensis are the only taxa from the Middle Devonian and Upper Devonian (Valiukevičius, 1985; Burrow, Janvier \& Villarroel, 2003; Pinakhina \& Märss, 2018). N. striata from many Silurian sites illustrates that it migrated widely (Pander, 1856; Fredholm, 1988; Märss, 1997; Burrow, 2013). N.consueta and N. amplifica might have migrated from the Baltica Block to South China (Valiukevičius, 2003c).

Some widely distributed 'acanthodians' such as Gomphonchus, Ischnacanthidae, Cheiracanthoides, Radioporacanthodes, Acanthodes and Machaeracanthus have also been found in China, as shown in Fig. 6 (Wang \& Dong, 1989; Gagnier et al., 1989; Wang, 1992; Wang et al., 1998; Burrow et al., 2000; Wang, 2003). But Nostolepoides mingyinensis, Gansuichthys liui, and Lijiangichthys lembodes were endemic to China (Wang et al., 1998; Wang, 2003). Most of these 'acanthodians' were described from the Devonian. But Ischnacanthus sp., Hanilepis wangi, Gomphonchus sp.,

Radioporacanthodes qujingensis, Gomphonchus sandelensis and Ischnacanthidae gen. indet. were reported from the Silurian (Wang \& Dong, 1989; Wang et al., 1998) and Acanthodes cf. A. dublinensis extends to the Eifelian (Burrow et al., 2000).

Almost all the Nostolepis were distributed around the Paleo-Tethys Ocean (Fig. 7). N. consueta, N. striata and N. amplifica described here (Xitun Formation, Lochkovian) were all recorded from the Baltica Block (Valiukevičius, 2003c; Valiukevičius, 2005). Our new data of Nostolepis from Qujing suggest a connection with East Baltica. N. striata is a cosmopolitan species, also described from the Laurentia and Australia blocks (Goujet,

PeerJ reviewing PDF | (2020:12:55998:1:1:NEW 10 Feb 2021) 
404 1976; Denison, 1979; Valiukevičius, 2005; Burrow et al., 2013; Turner \& Burrow, 2018).

405 Some other Nostolepis species, i.e., N. alifera, N. alta, N. elegans, N. costata, $N$.

406 robusta, $N$. magnicostata, $N$. minima, $N$. gaujensis, $N$. latvica, $N$. kozhymica, $N$.

407 parathleta, $N$. taimyrica, $N$. tcherkesovae, $N$. terraborea and $N$. linleyensis were also

408 recorded in the Baltica Block, but none of them has been reported in China

409 (Valiukevičius, 1994; Miller \& Märss, 1999; Valiukevičius, 2005; Pinakhina \& Märss, 410 2018). N. infida, N. arctica, N. matukhini, N. minima and N. taimyrica were also found in 411 Siberia blocks (Valiukevičius, 1994). N. costata scales was recorded in the Arabia and 412 some Nostolepis spp. were recorded in the Kazhakstan, Africa and Sibumasu blocks 413 (Blieck et al., 1984; Tông-Dzuy \& Janvier, 1994; Tông-Dzuy \& Janvier, 1990; Burrow et 414 al., 2006; Burrow et al., 2010).

415 In summary, most of the Nostolepis species range from the Upper Silurian to Lower 416 Devonian. Nostolepis is distributed mainly in the South China, Baltica, Siberia, 417 Laurentia, and Australia blocks, with rare records in the Arabia, Africa, Sibumasu and 418 Kazhakstan blocks. Biostratigraphic data of Nostolepis were very similar between the 419 South China and Baltica blocks.

420

421

422

423

424

425

426

427

428

429

430

431

432

433

434

435

436

437

438

439

440

441

442

443

444

445

\section{Acknowledgements}

We thank Qingming Qu (School of Life Sciences, Xiamen University) for providing constructive comments and suggestions that led to the improvement of our manuscript. We also thank Liantao Jia (IVPP) for the assistance in taking photographs, Yemao Hou (IVPP) and Pengfei Yin (IVPP) helped with CT scanning of some specimens.

\section{References}

Berg LS. 1940. Classification of fishes both recent and fossil. Trudy Instituta Zoologicheskikh Akademiia Nauk 5:85-517.

Brazeau MD. 2009. The braincase and jaws of a Devonian 'acanthodian' and modern gnathostome origins. Nature 457(7227):305-308 DOI 10.1038/nature07436.

Brotzen F. 1934. Erster Nachweis von Unterdevon im Ostseegebiete durch Konglomeratgeschiebe mit Fischresten. II. (Paläontologie). Zeitschrift für Geschiebeforschung 10(1):1-65.

Burrow CJ. 1997. Microvertebrate assemblages from the Lower Devonian (pesavis/sulcatus zones) of Central New South Wales, Australia. Modern Geology 21(1-2):43-77.

Burrow CJ, den Blaauwen J, Newman M, Davidson R. 2016. The diplacanthid fishes (Acanthodii, Diplacanthiformes, Diplacanthidae) from the Middle Devonian of Scotland. Palaeontologia Electronica 19(1):1-83.

Burrow CJ, Ivanov A, Rodina O. 2010. Emsian vertebrate microremains from the Zinzilban section, Uzbekistan. Palaeoworld 19(1-2):75-86 DOI 10.1016/j.palwor.2009.11.004.

Burrow CJ, Janvier P, Villarroel C. 2003. Late Devonian acanthodians from Colombia. Journal of South American Earth Sciences 16(2):155-161 DOI 10.1016/s0895- 
446

447

448

449

450

451

452

453

454

455

456

457

458

459

460

461

462

463

464

465

466

467

468

469

470

471

472

473

474

475

476

477

478

479

480

481

482

483

484

485

486

487

488

489

490

491

9811(03)00026-9.

Burrow CJ, Lelièvre H, Janjou D. 2006. Gnathostome microremains from the Lower Devonian Jawf Formation, Saudi Arabia. Journal of Paleontology 80(3):537-560 DOI 10.1666/0022-3360(2006)80[537:GMFTLD]2.0.CO;2.

Burrow CJ, Murphy MA. 2016. Early Devonian (Pragian) vertebrates from the northern Roberts Mountains, Nevada. Journal of Paleontology 90(4):734-740 DOI 10.1017/jpa.2016.58.

Burrow CJ. 2013. Reassessment of Ischnacanthus? scheii Spjeldnaes (Acanthodii, Ischnacanthiformes) from the latest Silurian or earliest Devonian of Ellesmere Island, arctic Canada. Canadian Journal of Earth Sciences 50(9):945-954 DOI 10.1139/cjes-2013-0068.

Burrow CJ, and Turner S. 2010. Reassessment of "Protodus" scoticus from the Early Devonian of Scotland. Morphology, Phylogeny and Paleobiogeography of Fossil Fishes München: Verlag Dr. Friedrich Pfeil 123-144.

Burrow CJ, Turner S, Nowlan GS, Denison RH. 2013. Vertebrate microremains from the Late Silurian of Arisaig, Nova Scotia, Canada. Journal of Paleontology 87:1041-1059 DOI 10.1666/12-154.

Burrow CJ, Turner S, Wang ST. 2000. Devonian microvertebrates from Longmenshan, Sichuan, China: Taxonomic assessment. Courier Forschungsinstitut Senckenberg 223(223):391-451.

Chang MM. 1982. The braincase of Youngolepis, a Lower Devonian crossopterygian from Yunnan, south-western China. Stockholm: University of Stockholm, Department of Geology.

Chang MM, Yu XB. 1984. Structure and phylogenetic significance of Diabolichthys speratus gen. et sp. nov., a new dipnoan-like form from the Lower Devonian of eastern Yunnan, China. Proceedings of the Linnean Society of New South Wales 107:171-184.

Davis SP, Finarelli JA, Coates MI. 2012. Acanthodes and shark-like conditions in the last common ancestor of modern gnathostomes. Nature 486:247-250 DOI 10.1038/nature11080.

Denison RH. 1979. Acanthodii. Stuttgart: Gustav Fischer Verlag.

Fredholm D. 1988. Vertebrates in the Ludlovian Hemse Beds of Gotland, Sweden. Geologiska Föreningens i Stockholm Förhandlingar 110:157-179.

Gagnier PY, Jahnke H, Shi Y. 1989. A fish fauna of the Lower Yulongsi Formation (Upper Silurian) of Qujing (E. Yunnan, S.W.China) and its depositional environment. Courier Forschungsinstitut Senckenberg 110:123-135.

Giles S, Friedman M, Brazeau MD. 2015. Osteichthyan-like cranial conditions in an Early Devonian stem gnathostome. Nature 520:82-85 DOI 10.1038/nature14065.

Goujet, D. 1976. Les Poissons, 312-323. In Babin, C. et al. (eds) Les Schistes et Calcaires odevoniens de Saint-Cenere (Massif Armoricain, France): Sedimentologie, Paleontologie, Stratigraphie. Mémoires de la Societé Géologique et Minéralogique de Bretagne 19.

Gross W. 1947. Die Agnathen und Acanthodier des Obersilurischen Beyrichienkalks. Palaeontographica Abteilung A 96:91-158.

Gross W. 1957. Mundzähne und Hautzähne der Acanthodier und Arthrodiren. Palaeontographica Abteilung A 109:1-40. 
492

493

494

495

496

497

498

499

500

501

502

503

504

505

506

507

508

509

510

511

512

513

514

515

516

517

518

519

520

521

522

523

524

525

526

527

528

529

530

531

532

533

534

535

536

Gross W. 1971. Downtonische und dittonische Acanthodier-Reste des Ostseegebietes. Palaeontographica Abteilung A 136(1-6):1-82.

Huang BC, Yan YG, Piper JDA, Zhang DH, Yi ZY, Yu S, Zhou TG. 2018.

Paleomagnetic constraints on the paleogeography of the East Asian blocks during Late Paleozoic and Early Mesozoic times. Earth-Science Reviews 186: 836 DOI 10.1016/j.earscirev.2018.02.004.

Long JA, Mark-Kurik E, Johanson Z, Lee MS, Young GC, Zhu M, Ahlberg PE, Newman M, Jones R, Blaauwen JD, Choo B, Trinajstic K. 2015. Copulation in antiarch placoderms and the origin of gnathostome internal fertilization. Nature 517:196-199 DOI 10.1038/nature13825.

Mader H. 1986. Schuppen und Zähne von Acanthodiern und Elasmobranchiern aus dem Unter-Devon Spaniens (Pisces). Göttinger Arbeiten zur Geologie und Paläontologie 28:1-58.

Märss T. 1997. Vertebrates of the Pridoli and Silurian-Devonian Boundary beds in Europe. Modern Geology 21(1):17-41.

Mergal M, Vaškaninová V, Žigaite Ž . 2017. Vertebrate microremains from the Pragian, Emsian and Eifelian of the Prague Basin (Czech Republic). Folia Musei rerum naturalium Bohemiae occidentalis. Geologica et Paleobiologica 51(1-2). DOI https://doi.org/10.1515/fbgp-2017-0001.

Miller CG, Märss T. 1999. A conodont, thelodont and acanthodian fauna from the Lower Pridoli (Silurian) of the Much Wenlock area, Shropshire. Palaeontology 42(4):691-714.

Owen R. 1846. Lectures on the Comparative Anatomy and Physiology of the Vertebrate Animals, Part I. London: Longman, Brown, Green and Longman.

Pander CH. 1856. Monographie der fossilen Fische des silurischen Systems der russischbaltischen Gouvernements. St Petersburg: Akademie der Wissenschaften.

Pinakhina DV, Märss T. 2018. The Middle Devonian acanthodian assemblage of the Karksi outcrop in Estonia. Estonian Journal of Earth Sciences 67(1):96-111 DOI 10.3176/earth.2018.07.

Plax DP. 2011. Devonian ichthyofauna of the Volyn Monocline. Lithosphere 35(2):1221.

Plax DP. 2015. Ichthyofauna from the Lower Devonian (Lochkovian) deposits of the southwestern part of Belarus. Lithosphere 43(2):19-36.

Tông-Dzuy T, Janvier P. 1990. Les vertébrés du Dévonien inférieur du Bac Bo oriental (provinces de Bac Thaï et Lang Son, Viêt Nam). Bulletin du Muséum national d'Histoire naturelle, Paris 4e sér, Section C 12(2):143-223.

Tông-Dzuy T, Janvier P. 1994. Early Devonian fishes from Trang Xa (Bac Thai, Vietnam), with remarks on the distribution of the vertebrates in the Song Cau Group. Journal of Southeast Asian Earth Sciences 10:235-243.

Turner S, Burrow CJ. 2018. Microvertebrates from the Silurian-Devonian boundary beds of the Eastport Formation, Maine, eastern USA. Atlantic Geology 54:171187 DOI 10.4138/atlgeol.2018.006.

Turner S, Burrow CJ, Williams RB, Tarrant P. 2017. Welsh Borderland bouillabaisse: Lower Old Red Sandstone fish microfossils and their significance. Proceedings of 
537

538

539

540

541

542

543

544

545

546

547

548

549

550

551

552

553

554

555

556

557

558

559

560

561

562

563

564

565

566

567

568

569

570

571

572

573

574

575

576

577

578

579

580

581

582

the Geologists' Association 128: 460-479 DOI 10.1016/j.pgeola.2017.04.006.

Valiukevičius J. 1985. Acanthodians from the Narva Regional Stage of the Main Devonian Field. Mokslas, Vilnius 1:144.

Valiukevičius J. 1994. Acanthodians and their stratigraphical significance. Stratigraphy and Fauna of the Lower Devonian of the Tareya Key Section (Taimyr), Leningrad, Nedra:131-197.

Valiukevičius J. 1998. Acanthodians and zonal stratigraphy of Lower and Middle Devonian in East Baltic and Byelorussia. Palaeontographica Abteilung A 248:153.

Valiukevičius J. 2003a. Devonian acanthodians from Severnaya Zemlya Archipelago (Russia). Geodiversitas 25(1):131-204.

Valiukevičius J. 2003b. New Late Silurian to Middle Devonian acanthodians of the Timan-Pechora region. Acta Geologica Polonica 53(3):209-245.

Valiukevičius J. 2003c. New Silurian nostolepids (Acanthodii, Pisces) of Lithuania. Geologija 42:51-68.

Valiukevičius J. 2004a. New Wenlock-Pridoli (Silurian) acanthodian fishes from Lithuania. Acta Palaeontologica Polonica 49(1):147-160.

Valiukevičius J. 2004b. Silurian acanthodian succession of the Luzni-4 borehole (Latvia). Acta Universitatis Latviensis 679:120-147.

Valiukevičius J. 2005. Silurian acanthodian biostratigraphy of Lithuania. Geodiversitas 27(3):349-380.

Valiukevičius J, Burrow CJ. 2005. Diversity of tissues in acanthodians with Nostolepis-type histological structure. Acta Palaeontologica Polonica 50(3):635649.

Vergoossen JMJ. 1999. Late Silurian fish microfossils from an East Baltic-derived erratic from Oosterhaule, with a description of new acanthodian taxa. Geologie en Mijnbouw 78(2):231-251.

Vergoossen JMJ. 2000. Acanthodian and chondrichthyan microremains in the SiluroDevonian of the Welsh Borderland, Great Britain, and their biostratigraphical potential. Courier Forschungsinstitut Senckenberg 223:175-200.

Vergoossen JMJ. 2002a. Late Silurian fish microfossils from Ramsåsa, locality $H$, Scania, South Sweden, with some remarks on the body zonation scheme used in thelodont studies. Scripta Geologica 123:41-69.

Vergoossen JMJ. 2002b. Late Silurian fish microfossils from Klinta and Rinnebäcks Bro (Scania, South Sweden), with remarks on the morphology of Nostolepis striata trunk scales. Scripta Geologica 123:71-92.

Vergoossen JMJ. 2003a. First record of fish microfossils from Ramsåsa, site C, Skåne, southern Sweden. Scripta Geologica 126:1-78.

Vergoossen JMJ. 2003b. Fish microfossils from the Upper Silurian Oved Sandstone Formation, Skane, southern Sweden. Ph.D. Rijksuniversiteit Groningen.

Vergoossen JMJ. 2004. Fish microfossils from Ramsasa, site E, Scania, southern Sweden (mid Palaeozoic). National Natuurhistorisch Museum.

Wang HH, Ma XP, Ladislav S, Wei F, Zhang MQ, Lv D. 2018. Lower Devonian conodont biostratigraphy of the Alengchu Section in Western Yunnan Province, South China. Journal of Stratigraphy 42(3):288-300.

Wang NZ. 1984. Thelodont, acanthodian, and chondrichthyan fossils from the Lower

Peer) reviewing PDF | (2020:12:55998:1:1:NEW 10 Feb 2021) 
583

584

585

586

587

588

589

590

591

592

593

594

595

596

597

598

599

600

601

602

603

604

605

606

607

608

609

610

611

612
Devonian of southwestern China. Proceedings of the Linnean Society of New South Wales 107:419-441.

Wang NZ. 1992. Microremains of agnathans and fishes from Lower Devonian of Central Guangxi with correlation of Lower Devonian between central Guangxi and eastern Yunnan, South China. Acta Palaeontologica Sinica 31(3):280-303.

Wang NZ, Dong ZZ. 1989. Discovery of Late Silurian microfossils of Agnatha and fishes from Yunnan, China. Acta Palaeontologica Sinica 28(2):192-206.

Wang NZ, Wang JQ, Zhang GR, Wang ST. 1998. The first discovery of Silurian and Early Devonian acanthodians from Zoige and Tewo counties, west Qinling Mountains. Vertebrata PalAsiatica 36(4):268-281.

Wang W. 2003. First occurrence of acanthodian microfossils from the Early Devonian of Lijiang, Yunnan, China. Vertebrata PalAsiatica 41(1):1-16.

Zhao WJ, Zhu M. 2015. A review of Silurian fishes from Yunnan, China and related biostratigraphy. Palaeoworld 24(1-2):243-250 DOI 10.1016/j.palwor.2015.02.004.

Zhu M. 1996. The phylogeny of the Antiarcha (Placodermi, Pisces), with the description of Early Devonian antiarchs from Qujing, Yunnan, China. Bulletin du Muséum national d'Histoire naturelle 18:233-347.

Zhu M, Yu XB. 2002. A primitive fish close to the common ancestor of tetrapods and lungfish. Nature 418(6899):767-770 DOI 10.1038/nature00871.

Zhu M, Yu XB, Ahlberg PE. 2001. A primitive sarcopterygian fish with an eyestalk. Nature 410(6824):81-84 DOI 10.1038/35065078.

Zhu M, Yu XB, Janvier P. 1999. A primitive fossil fish sheds light on the origin of bony fishes. Nature 397:607-610 DOI 10.1038/17594.

Zhu M, Yu XB, Wang W, Zhao WJ, Jia LT. 2006. A primitive fish provides key characters bearing on deep osteichthyan phylogeny. Nature 441(7089):77-80 DOl 10.1038/nature04563.

Zhu M, Yu XB, Ahlberg PE, Choo B, Lu J, Qiao T, Qu QM, Zhao WJ, Jia LT, Blom H, Zhu YA. 2013. A Silurian placoderm with osteichthyan-like marginal jaw bones. Nature 502(7470):188-193 DOI 10.1038/nature12617. 


\section{Figure 1}

Figure 1: SEM photos of Nostolepis striata, Nostolepis amplifica and Nostolepis consueta scales.

(A)-(H) Nostolepis striata. (A) Crown view, IVPP V26830.1. (B) Crown view, IVPP V26830.2. (C) Crown view, IVPP V26830.3. (D) Crown view, IVPP V26830.4. (E) Crown view, IVPP V26830.5. (F) Base view and (G) Crown view, IVPP V26830.6. (H) Crown view, IVPP V26830.7. (I)-(P) Nostolepis amplifica. (I) Crown view and (J) Antero-lateral view, IVPP V26832.1. (K) Crown view and (L) Antero-lateral view, IVPP V26832.2. (M) Crown view and (N) Lateral view, IVPP V26832.3. (O) Crown view and (P) Base view, IVPP V26832.4. (Q)-(X) Nostolepis consueta. (Q) Crown view and (R) Postero-lateral view, IVPP V26834.1. (S) Antero-lateral view, IVPP V26834.2. (T) Crown view and (U) Base view, IVPP V26834.3. (V) Crown view and (W) Anterolateral view, IVPP V26834.4. (X) Antero-lateral view, IVPP V26834.5. Scale bars $0.1 \mathrm{~mm}$. Early Devonian, Lochkovian, the Xitun Formation, Qujing. 


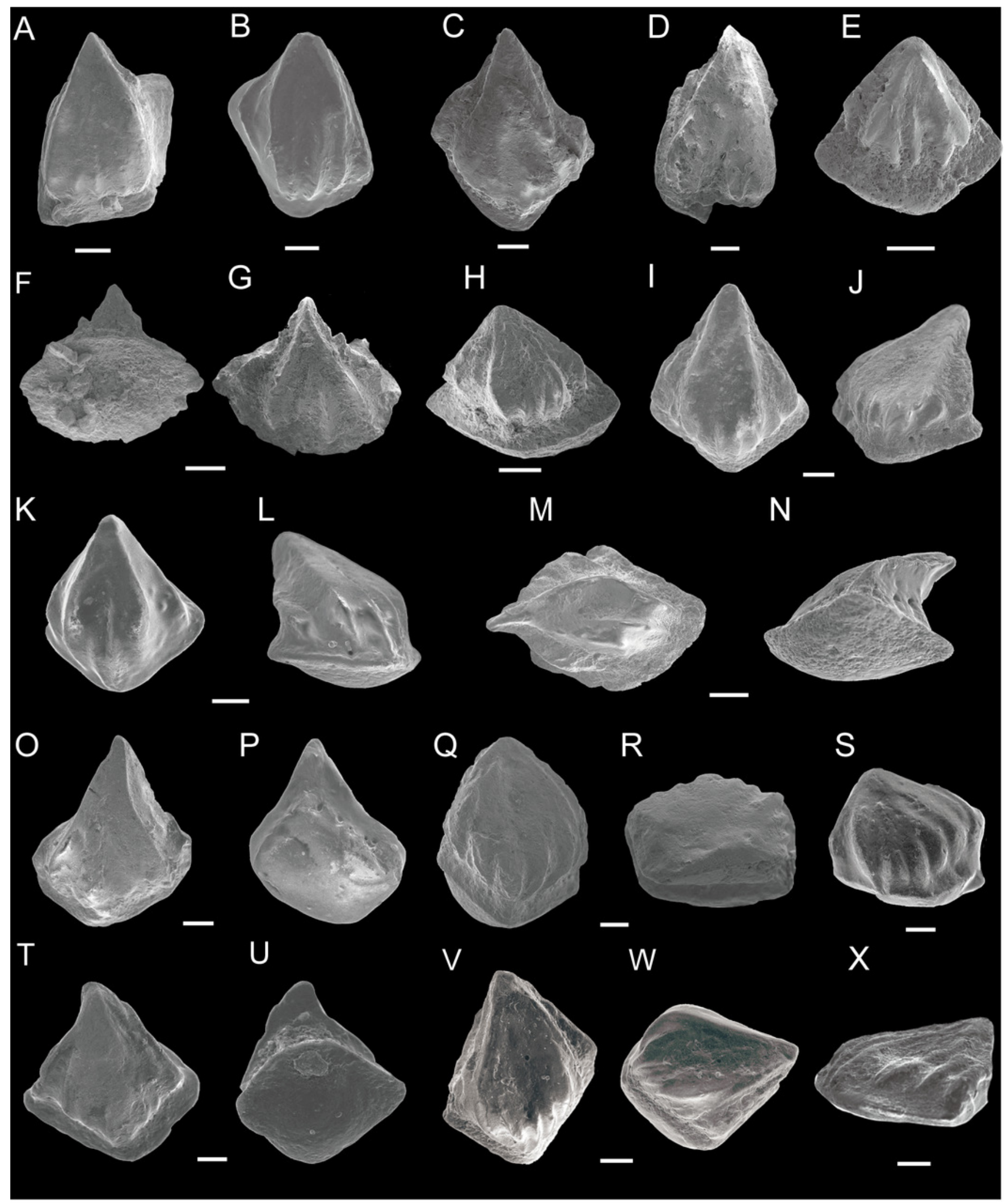


Figure 2

Figure 2: Histological microstructure and illustrative drawings of Nostolepis striata, Nostolepis amplifica, and Nostolepis consueta scales in vertical longitudinal sections.

(A)-(B) Nostolepis striata , V26831. (C)-(D) Nostolepis amplifica, V26833. (E)-(F) Nostolepis consueta, V26835. dt-dentine tubule; oc-osteocyte cavity; stg-Stranggewebe; gl-growth lamella; avc-ascending vascular canal; sf-Sharpey's fibers. Scale bars $0.1 \mathrm{~mm}$. 

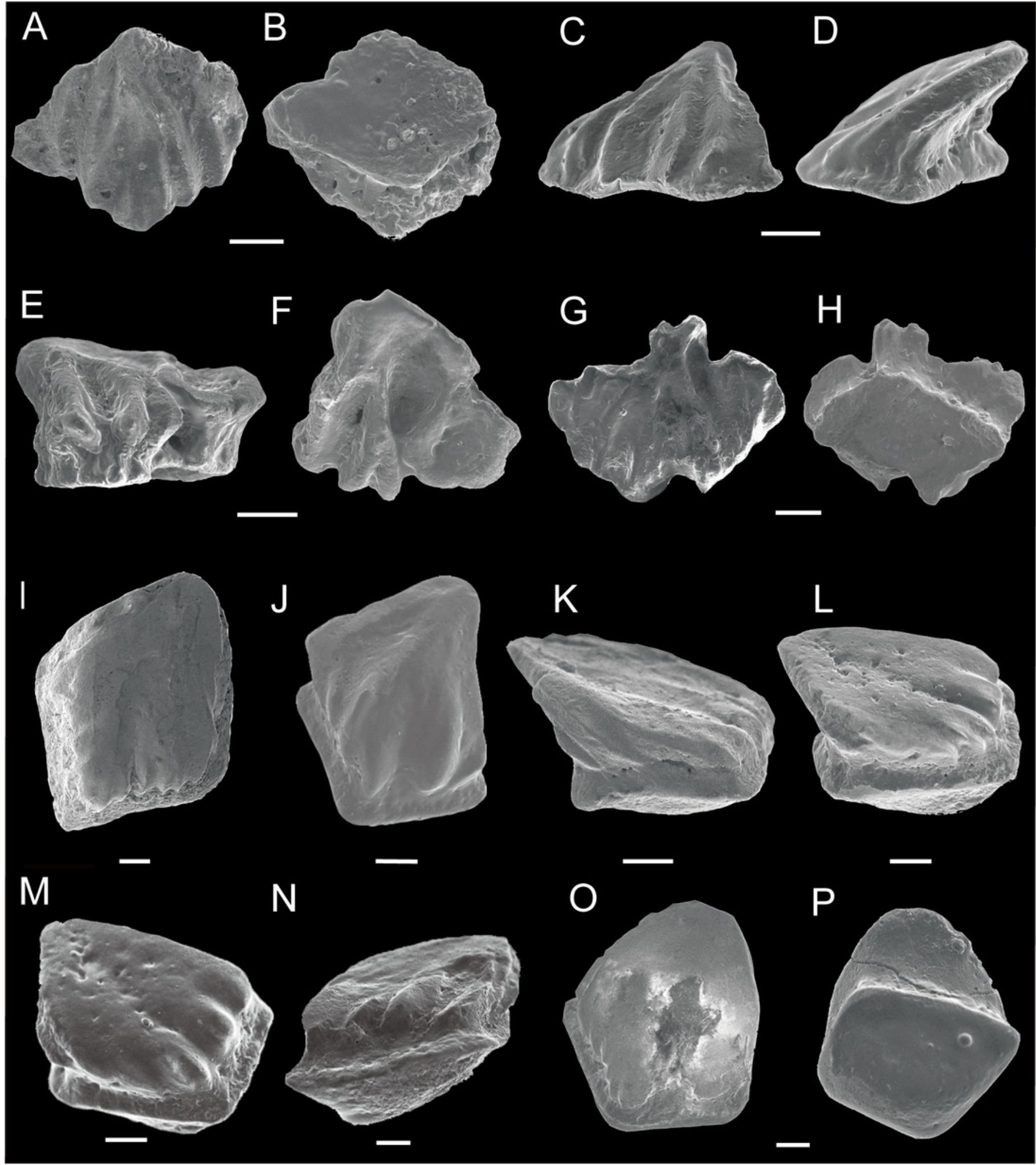


\section{Figure 3}

Figure 3: SEM photos of Nostolepis qujingensis sp. nov. and Nostolepis digitus sp. nov. scales.

(A)-(H) Nostolepis qujingensis sp. nov . (A) Crow view and (B) Base view, IVPP V26838.1, holotype. (C) Crown view and (D) Lateral view , IVPP V26838.2 . (E) Antero-lateral view and (F) Crown view, IVPP V26838.3. (G) Crown view and (H) Base view, IVPP V26838.4. (I)-(P) Nostolepis digitus sp. nov. (I) Crown view, IVPP V26840.1, holotype. (J) Crown view, IVPP V26840.2. (K) Antero-lateral view, IVPP V26840.3. (L) Antero-lateral view, IVPP V26840.4. (M) Antero-lateral view, IVPP V26840.5. (N) Lateral view, IVPP V26840.6. (0) Crown view and (P) Base view, IVPP V26840.7. Scale bars $0.1 \mathrm{~mm}$. Early Devonian, Lochkovian, Xitun Formation, Qujing. 

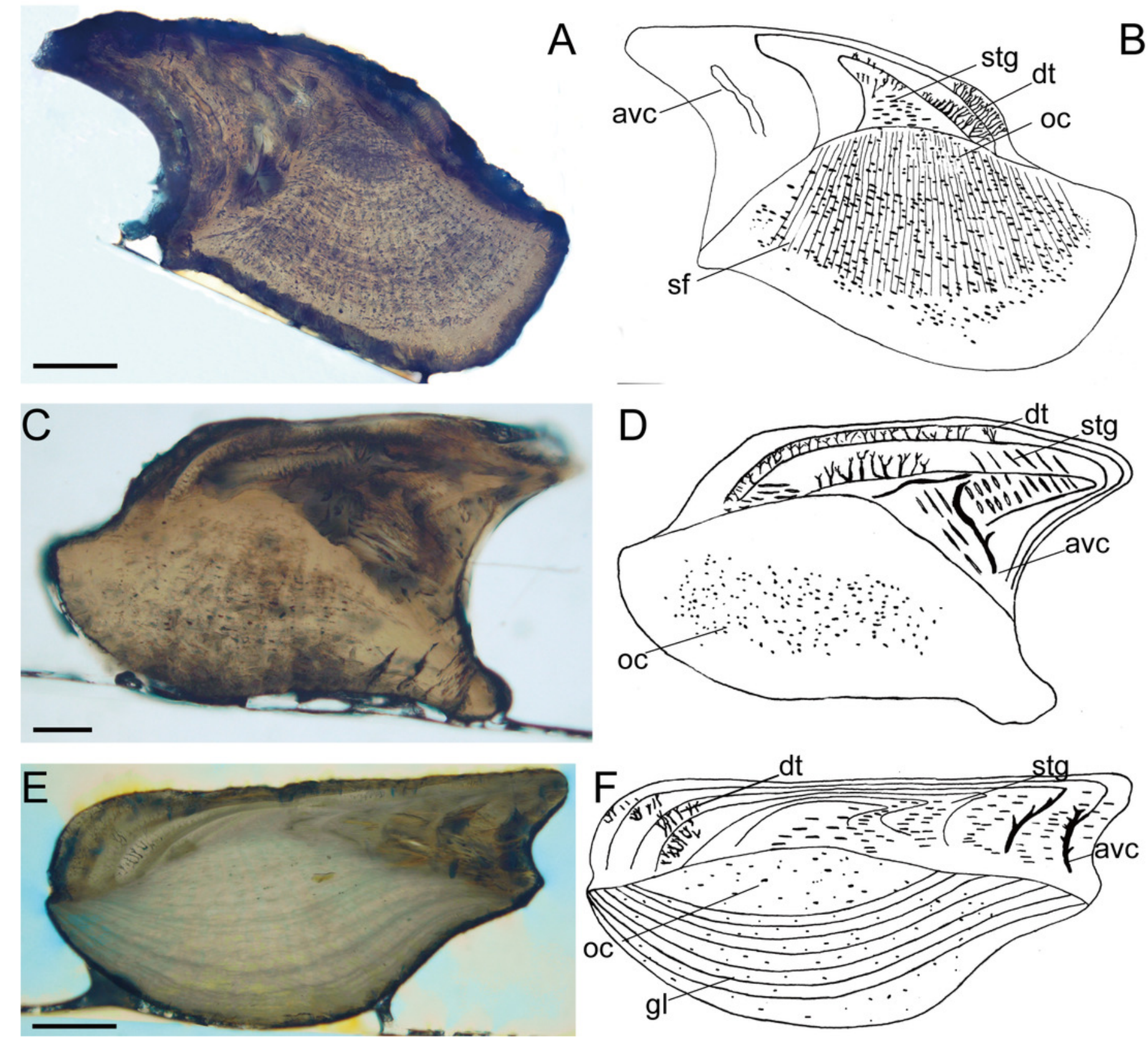


\section{Figure 4}

Figure 4: Histological microstructure and illustrative drawings of Nostolepis qujingensis s p. nov. and Nostolepis digitus sp. nov. scales in vertical longitudinal sections.

(A)-(D) Nostolepis qujingensis sp. nov. (A)-(B) V26839. (C) V26839.2. (D) V26839.3 (E)-(H) Nostolepis digitus sp. nov. (E)-(F) V26841. (G) V26841.2. (H) V26841.3. dt-dentine tubule; ocosteocyte cavity; stg-Stranggewebe; gl-growth lamella; avc-ascending vascular canal; sfSharpey's fibers. Scale bars $0.1 \mathrm{~mm}$. 

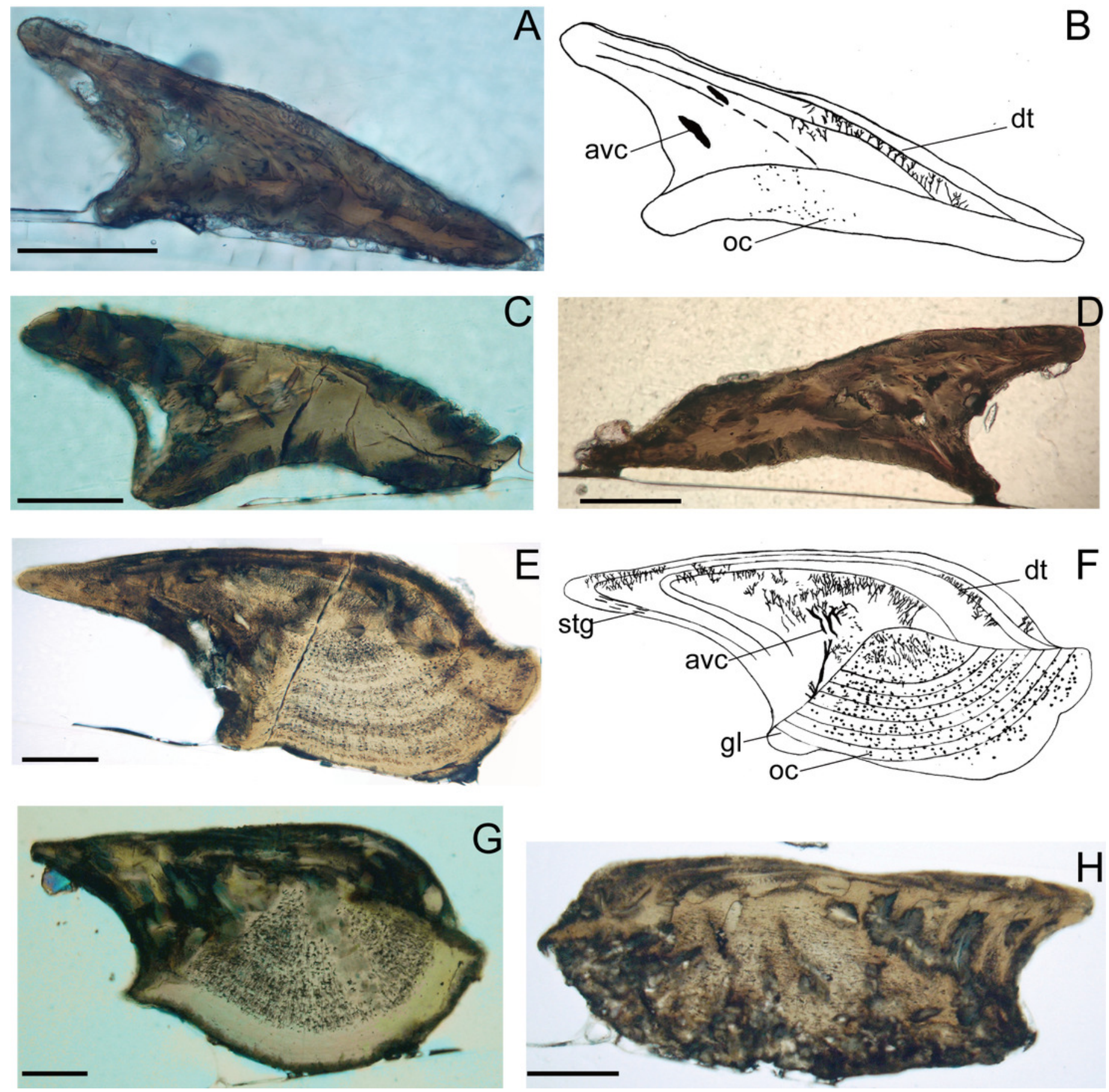
Figure 5

Figure 5: Stratigraphical ranges of Nostolepis in the world and acanthodians in China from Silurian to Middle Devonian.

Modified from Wang, 2003; Valiukevičius, 2003b; Valiukevičius, 2005 and Zhao \& Zhu, 2015. 


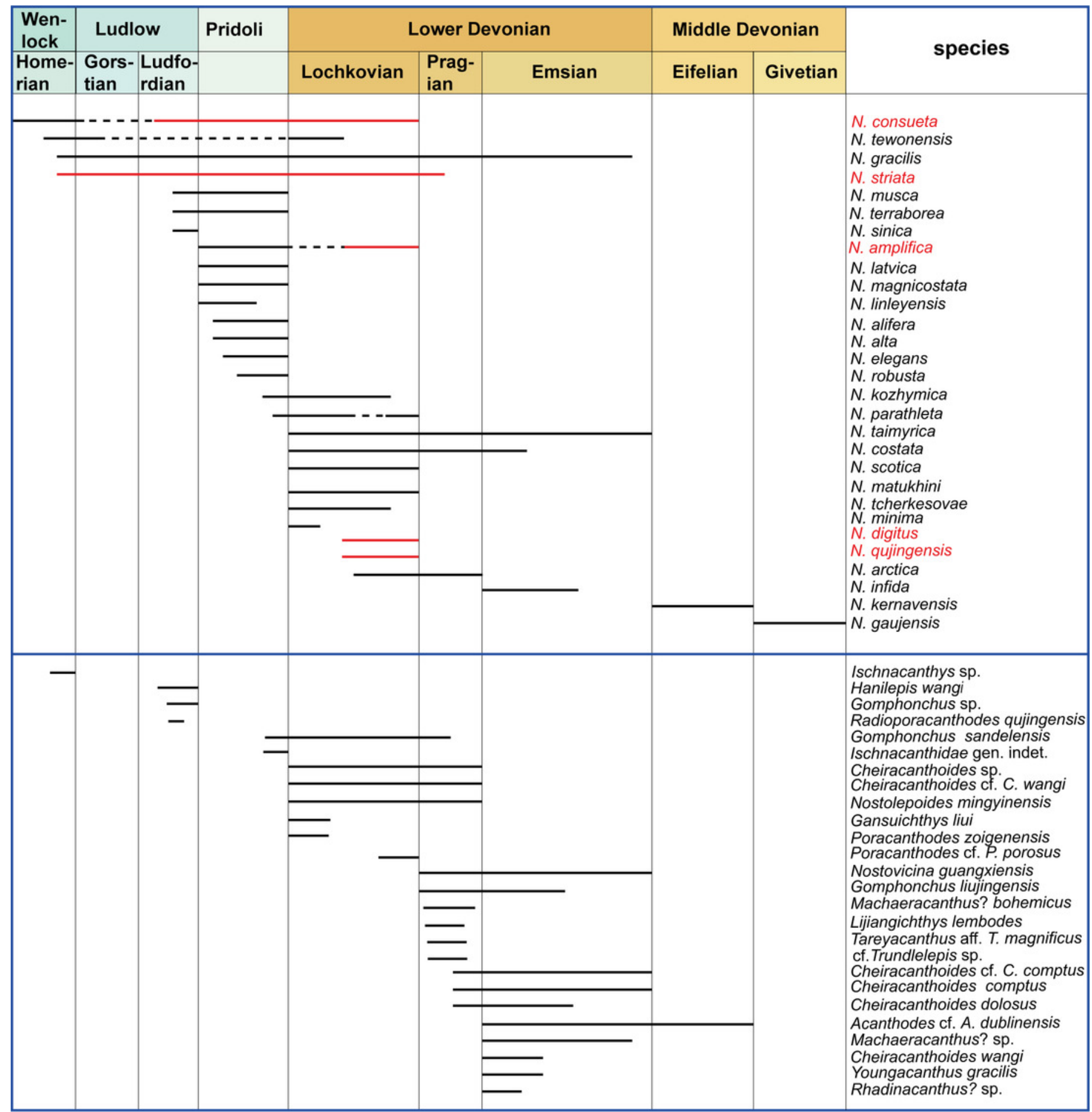




\section{Figure 6}

Figure 6: Nostolepis distribution in Lower Palaeozoic terranes around $400 \mathrm{Ma}$ (Early Devonian).

Modified from Huang et al., 2018.

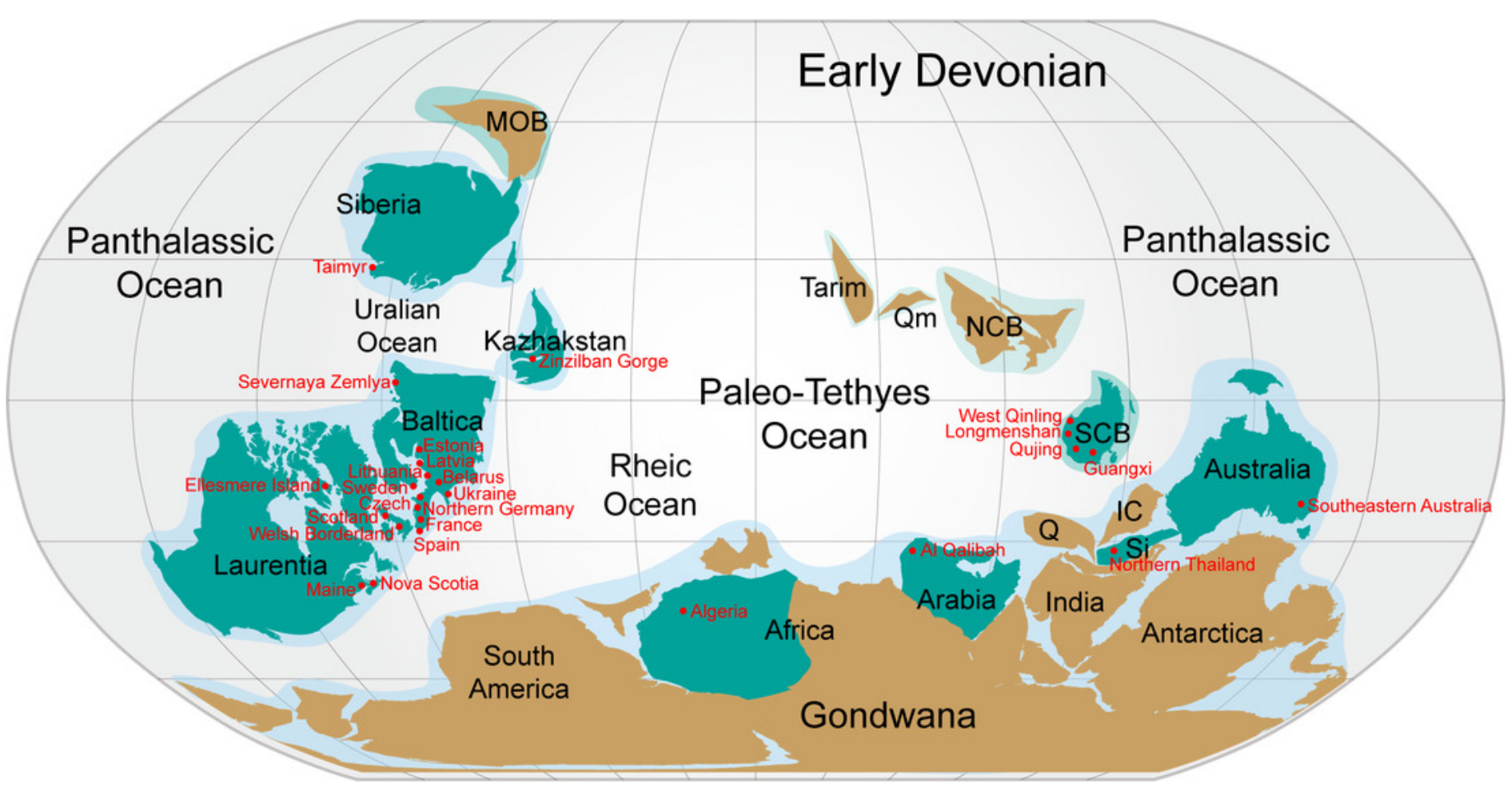

